\title{
Pengaruh Penambahan Asam Sitrat Terhadap Proses Non-Enzimatik Browning Jus Buah Pir Yali (Pyrus bretschneideri Rehd.)
}

\section{The Effect of Citric Acid Treatment on The Non-Enzymatic Browning of Yali Pear Juice (Pyrus bretschneideri Rehd.)}

\section{Victoria Agatha Angela Sirait ${ }^{*}$, Zulkifli, Tundjung Tripeni Handayani, Martha Lulus Lande}

Jurusan Biologi FMIPA Universitas Lampung

*Email: victoria.agatha1123@students.unila.ac.id

\begin{abstract}
The purpose of this study was to find out how effective citric acid is against the nonenzymatic process of browning Yali Pear fruit juice (Pyrus bretschneideri Rehd. The research was conducted in a complete randomized design consisting of 5 replications. The non-enzymatic browning inhibition process was tested with citric acid treatment as the main factor with five concentrations ie $0 \% \mathrm{w} / \mathrm{v}, 2,5 \% \mathrm{w} / \mathrm{v}, 5 \% \mathrm{w} / \mathrm{v}, 7,5 \% \mathrm{w} / \mathrm{v}$ and $10 \% \mathrm{w} / \mathrm{v}$. Qualitative parameters were dehydrogenase enzyme activity and reducing sugar level. Quantitative parameters were browning index and total soluble carbohydrate content. Levene test, analysis of variance, and Tukey test were performed at 5\% significant level. The results showed that decrease in dehydrogenase enzyme activity occurs along with increasing the concentration of citric acid. The level of reducing sugar has increased along with the increase of citric acid concentration. The 7,5\% w/v citric acid concentration effectively inhibited non-enzymatic browning of Yali Pear juice with a $21 \%$ reduction in the browning index. Total soluble carbohydrate content increased $7 \%$ at $7.5 \% \mathrm{w} / \mathrm{v}$ citric acid concentration. From the results of the study it was concluded that citric acid at 7,5\% $\mathrm{w} / \mathrm{v}$ concentration was the inhibitor of non-enzymatic browning and dehydrogenase enzyme activity, but stimulator of total soluble carbohydrate and reducing sugar level.
\end{abstract}

Keywords: browning, citric acid, Yali Pear

Disubmit : 8 Juli 2018, Diterima: 8 Agustus 2018, Disetujui : 10 September 2018

\section{PENDAHULUAN}

Buah pir kaya akan kandungan gizi maupun kalori sebesar 110 kal dan kalium sebesar $134 \mathrm{mg}$ yang sangat berguna bagi tubuh. Menurut Wijaya (2008), buah pir mengandung senyawa katekin yang bersifat antibakteri sehingga menghambat pembentukan plak gigi. Khasiat lain yang juga didapatkan dari mengkonsumsi buah pir secara rutin yaitu mencegah kanker dan memperlancar saluran pencernaan.

Buah pir dapat dikonsumsi dengan berbagai cara, misalnya dimakan sebagai buah segar, buah kaleng dan minuman jus. Pengolahan buah pir dilakukan dalam beberapa tahap, diantaranya pengupasan kulit yang sering menyebabkan luka pada jaringan buah. Akibatnya buah mengalami infeksi dan terjadi proses browning (Buckle, 1987).

Menurut Rahmawati (2008), browning adalah suatu proses terbentuknya pigmen berwarna kuning pada buah yang telah terbuka akibat tergores, terluka atau tersayat yang menyebabkan buah berubah menjadi 
warna coklat gelap. Reaksi pencoklatan dapat didefinisikan sebagai peristiwa dimana gugus asam amino dari protein bereaksi dengan gugus aldehida atau keton dari gula pereduksi dan menghasilkan warna coklat (Azis, 2016).

Browning mengurangi kualitas produk bahan pangan segar sehingga menurunkan nilai ekonominya. Penurunan nilai ekonomi terjadi karena perubahan rasa pada buah (Blackwell, 2012). Perubahan rasa dan penurunan kualitas tersebut juga berlaku pada pengolahan jus buah pir. Untuk menghambat terjadinya browning berbagai cara dapat dilakukan, misalnya pemanasan dan pemberian larutan asam sitrat.

Menurut Padmadisastra et al. (2003) pemanasan akan menginaktivasi enzim-enzim yang terlibat dalam reaksi browning. Enzim umumnya bereaksi optimum pada suhu $30-40{ }^{\circ} \mathrm{C}$. Pada suhu $45^{\circ} \mathrm{C}$ enzim mulai terdenaturasi dan pada suhu $60^{\circ} \mathrm{C}$ enzim mengalami dekomposisi, termasuk enzim PPO yang menyebabkan browning pada buah. Menurut Zulfahnur, dkk (2009) pencegahan reaksi browning pada produk pangan dapat dilakukan dengan penurunan $\mathrm{pH}$ pangan melalui penambahan asam sitrat, asam askorbat, asam asetat, larutan natrium metabisulfit dan larutan sirup gula. Sesuai dengan Pradhana dan Karouw (2016), konsentrasi asam sitrat $1 \%$ dan natrium metabisulfit $2 \%$ dengan pencelupan masing-masing selama 10 menit efektif mencegah pencoklatan dan kekerutan pada permukaan kelapa muda segar. Penurunan pH dilakukan karena reaksi browning umumnya terjadi pada pH 9 sampai pH 10,5 (Eriksson, 1981).

Namun proses pemanasan dapat menyebabkan non-enzimatik browning. Eskin et al. (1971) menyatakan, reaksi non-enzimatik browning merupakan reaksi yang tidak melibatkan peran enzim. Reaksi browning non-enzimatik terdiri dari tiga macam yaitu karamelisasi, reaksi Maillard, dan oksidasi vitamin C. Berdasarkan uraian diatas maka dilakukan percobaan lanjutan untuk mengetahui pengaruh dari asam sitrat dan temperatur terhadap browning pada jus buah pir. Browning pada jus buah Pir Yali di evaluasi berdasarkan warna jus, aktivitas enzim dehidrogenase, level gula pereduksi, indeks browning dan kandungan karbohidrat terlarut total. Tujuan penelitian ini adalah menganalisis efek penambahan asam sitrat dengan berbagai konsentrasi terhadap proses non-enzimatik browning jus buah Pir Yali.

\section{METODE PENELITIAN}

Penelitian ini dilaksanakan di Laboratorium Botani, Jurusan Biologi, Fakultas Matematika dan Ilmu Pengetahuan Alam, Universitas Lampung, pada bulan Oktober sampai November 2017 dalam Rancangan Acak Lengkap (RAL). Faktor utama adalah asam sitrat dengan 5 taraf konsentrasi : 0\% b/v, 2,5\% b/v, 5\% $\mathrm{b} / \mathrm{v}, 7,5 \% \mathrm{~b} / \mathrm{v}$ dan $10 \% \mathrm{~b} / \mathrm{v}$. Setiap perlakuan diulang 5 kali sehingga jumlah seluruh satuan percobaan adalah 25. Parameter kualitatif adalah aktivitas enzim dehidrogenase dan level gula pereduksi. Sedangkan parameter kuantitatif adalah nilai tengah $(\mu)$ indeks browning dan kandungan karbohidrat terlarut total.

Untuk mendapatkan jus buah Pir Yali, 100 gram daging buah diproses dengan juicer. Jus yang diperoleh dimasukkan ke dalam beaker glass. Selanjutnya, $10 \mathrm{ml}$ jus dipipet ke dalam tabung reaksi yang telah dilabel dengan perlakuan dan ulangan. Semua tabung reaksi ditutup rapat dengan plastik dan diikat dengan karet gelang. Seluruh tabung reaksi dipanaskan dengan hotplate sampai temperatur $60{ }^{\circ} \mathrm{C}$. Seluruh tabung didiamkan sampai temperatur turun menjadi $50{ }^{\circ} \mathrm{C}$. Pada saat temperatur stabil $50{ }^{\circ} \mathrm{C}$ sebagai kontrol ke dalam tabung reaksi ditambahkan $2 \mathrm{ml}$ aquadest, dan sebagai perlakuan masing-masing ke dalam 5 tabung reaksi ditambahkan $2 \mathrm{ml}$ asam sitrat dengan konsentrasi 2,5\%,5\%,7,5\% dan $10 \%$ dan diinkubasi selama 72 jam.

Aktivitas enzim dehidrogenase dievaluasi berdasarkan metoda methylene blue (Witham et al., 1986). 2 $\mathrm{ml}$ jus buah Pir Yali dimasukkan ke dalam tabung reaksi dan ditambahkan methylene blue 0,025\% (b/v) sampai memenuhi tabung reaksi lalu ditutup rapat dengan plastik dan diikat menggunakan karet gelang, selanjutnya dilanjutkan dengan inkubasi selama 24 jam. Aktivitas enzim dehidrogenase diduga berdasarkan perubahan warna larutan methylene blue. Semakin bening warna methylene blue semakin tinggi aktivitas 
enzim dehidrogenase. Gula pereduksi dideteksi dengan uji Benedict. $2 \mathrm{ml}$ jus buah Pir Yali ditambahkan 3 $\mathrm{ml}$ Benedict dan dipanaskan selama 10 menit. Endapan warna merah bata yang terbentuk menunjukkan gula pereduksi. Indeks browning ditentukan menurut Jeong et al. (2008). Absorbansi jus buah Pir Yali diukur dengan spektrofotometer pada panjang gelombang $420 \mathrm{~nm}$. Semakin besar nilai absorbansi semakin tinggi indeks browning. Kandungan karbohidrat terlarut total ditentukan dengan metoda fenol sulfur. 2 ml jus dimasukkan kedalam tabung reaksi dan ditambahkan $2 \mathrm{ml}$ larutan $\mathrm{H}_{2} \mathrm{SO}_{4}$ pekat dan $1 \mathrm{ml}$ larutan fenol. Jus dibiarkan beberapa saat sampai berwarna coklat kemerahan yang menunjukan karbohidrat terlarut. Absorbansi diukur dengan spektrofotometer UV dengan panjang gelombang $490 \mathrm{~nm}$. Nilai absorbansi setiap jus buah Pir Yali dicatat. Kandungan karbohidrat ditentukan berdasarkan kurva standar glukosa dan dinyatakan dalam satuan $\mathrm{mg} / \mathrm{ml}$ jus.

Uji Levene, analisis ragam dan uji Tukey dilakukan pada taraf nyata 5\%. Korelasi antara konsentrasi asam sitrat dengan indeks browning dan kandungan karbohidrat terlarut total ditentukan dengan regresi.

\section{HASIL DAN PEMBAHASAN}

Warna jus buah Pir Yali. Warna jus buah Pir Yali setelah pemanasan dan penambahan asam sitrat dapat dilihat pada Gambar 1.

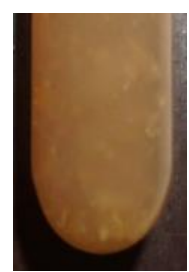

$0 \% \mathrm{~b} / \mathrm{v}$

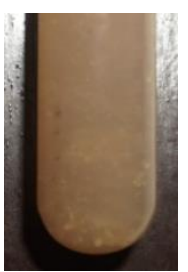

$2,5 \% \mathrm{~b} / \mathrm{v}$

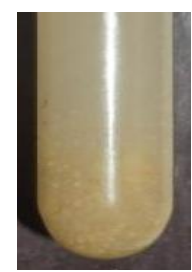

$5 \% \mathrm{~b} / \mathrm{v}$

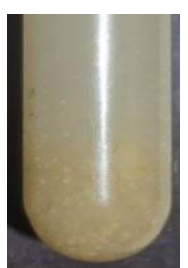

$7,5 \% \mathrm{~b} / \mathrm{v}$

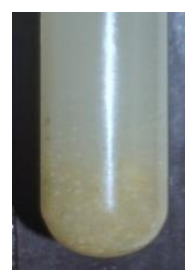

$10 \% \mathrm{~b} / \mathrm{v}$

Gambar 1. Warna jus buah Pir Yali setelah diinkubasi 72 jam.

Hasil pengamatan menunjukkan bahwa warna jus Pir Yali perlakuan relatif lebih terang dari kontrol. Hal ini menunjukkan bahwa asam sitrat menghambat proses browning jus buah Pir Yali. Hal ini sesuai dengan Arsa (2016) bahwa asam sitrat termasuk asidulan, yaitu senyawa kimia bertindak sebagai penegas rasa dan warna. Asam sitrat (yang banyak terdapat dalam lemon) sangat mudah teroksidasi dan digunakan sebagai pengikat oksigen untuk mencegah buah berubah menjadi berwarna coklat.

Indeks Browning. Pengaruh asam sitrat terhadap indeks browning jus buah Pir Yali dapat dilihat pada Tabel 1.

Tabel 1. Rata - rata indeks browning jus buah Pir Yali

\begin{tabular}{cc}
\hline $\begin{array}{c}\text { Konsentrasi Asam Sitrat } \\
(\% \mathrm{~b} / \mathrm{v})\end{array}$ & Indeks Browning \\
$\overline{\mathrm{Y}} \pm \mathrm{SE}$ \\
\hline 0 (kontrol) & $1.70 \pm 0.08^{\mathrm{a}}$ \\
2,5 & $1.55 \pm 0.07^{\mathrm{a}}$ \\
5 & $1.43 \pm 0.07^{\mathrm{ab}}$ \\
7,5 & $1.34 \pm 0.09^{\mathrm{b}}$ \\
10 & $1.16 \pm 0.09^{\mathrm{b}}$
\end{tabular}

Keterangan: angka-angka yang diikuti oleh huruf yang sama tidak berbeda nyata.

Analisis ragam pada taraf nyata 5\% menunjukkan bahwa asam sitrat berpengaruh nyata terhadap indeks browning jus buah Pir Yali $(\mathrm{P}<0,05)$. Uji Tukey menunjukkan bahwa indeks browning jus buah Pir Yali kontrol berbeda nyata dari indeks browning jus buah Pir Yali perlakuan asam sitrat 7,5\% b/v $(\mathrm{P}<0,05)$ dan dari indeks browning jus buah Pir Yali perlakuan asam sitrat $10 \% \mathrm{~b} / \mathrm{v}(\mathrm{P}<0,01)$. Antar perlakuan indeks browning jus buah Pir Yali perlakuan 2,5\% b/v berbeda nyata dari indeks browning jus buah Pir Yali 
perlakuan $10 \%$ b/v. Sehingga sesuai dengan Iyengar dan Evily (1992), asam organik seperti asam sitrat digunakan untuk menghambat reaksi browning dengan menurunkan $\mathrm{pH}$ dibawah 3, sehingga enzim polifenol oksidase menjadi inaktif. Selain itu didukung oleh De man (1997) reaksi pencoklatan diperlambat oleh penurunan $\mathrm{pH}$ dan reaksi pencoklatan dapat dikatakan bersifat menghambat sendiri karena $\mathrm{pH}$ menurun dengan bilangannya gugus asam amino basa.

Korelasi antara konsentrasi asam sitrat dengan indeks browning jus buah Pir Yali ditunjukkan pada Gambar 2.

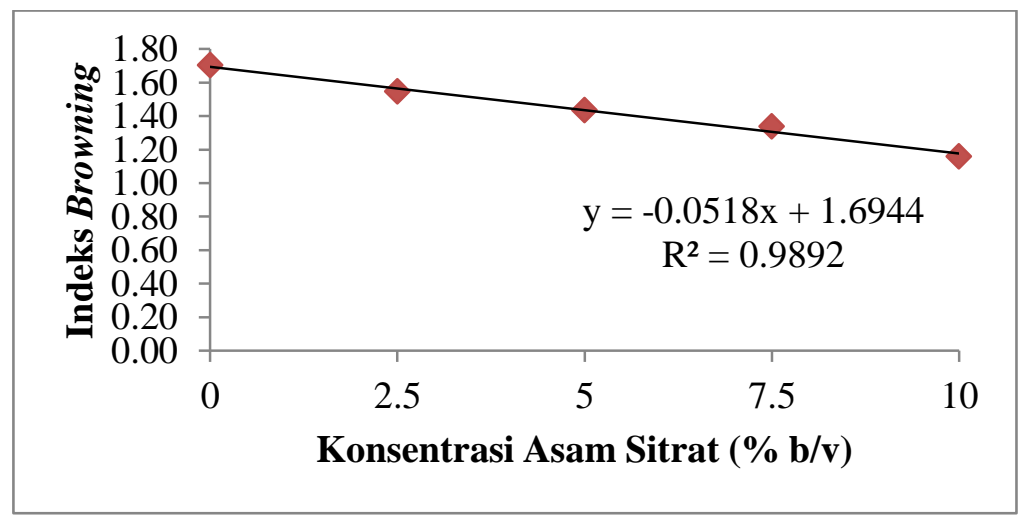

Gambar 2. Kurva regresi antara konsentrasi asam sitrat dengan indeks browning jus buah Pir Yali.

Menurut Wulandari (2016) uji BNT taraf nyata 5\% menunjukkan indeks browning buah Pir Yali berkorelasi negatif (strong negative relationship) dengan konsentrasi asam sitrat. Hal tersebut sesuai dengan penelitian dengan jus buah Pir Yali. Analisis regresi menunjukkan bahwa konsentrasi asam sitrat berkorelasi linear negatif dengan indeks browning jus buah Pir Yali dengan koefisien determinasi adalah 0,989 dan koefisien korelasi adalah -0,995 yang menunjukkan korelasi yang kuat antara konsentrasi asam sitrat dengan indeks browning jus buah Pir Yali.

Kandungan Karbohidrat Terlarut Total. Pengaruh asam sitrat terhadap kandungan karbohidrat terlarut total jus buah Pir Yali dapat dilihat pada Tabel 2.

Tabel 2. Rata-rata kandungan karbohidrat terlarut total jus buah Pir Yali (mg/ml jus)

\begin{tabular}{cc}
\hline $\begin{array}{c}\text { Konsentrasi Asam Sitrat } \\
(\% \mathrm{~b} / \mathrm{v})\end{array}$ & Kandungan Karbohidrat Terlarut Total \\
$\overline{\mathrm{Y}} \pm \mathrm{SE}$ \\
\hline 0 (kontrol) & $0.898 \pm 0.010^{\mathrm{a}}$ \\
2,5 & $0.917 \pm 0.021^{\mathrm{a}}$ \\
5 & $0.927 \pm 0.013^{\mathrm{a}}$ \\
7,5 & $0.959 \pm 0.017^{\mathrm{b}}$ \\
10 & $0.961 \pm 0.010^{\mathrm{b}}$ \\
\hline
\end{tabular}

Keterangan: angka-angka yang diikuti dengan huruf yang sama tidak berbeda nyata.

Analisis ragam pada taraf nyata 5\% menunjukkan bahwa asam sitrat berpengaruh nyata terhadap kandungan karbohidrat terlarut total jus buah Pir Yali $(\mathrm{P}<0,05)$. Uji Tukey menunjukkan bahwa kandungan karbohidrat terlarut total jus buah Pir Yali kontrol berbeda nyata dari kandungan karbohidrat terlarut total jus buah Pir Yali perlakuan asam sitrat 7,5\% b/v $(\mathrm{P}<0,05)$ dan dari kandungan karbohidrat terlarut total jus buah Pir Yali perlakuan asam sitrat $10 \% \mathrm{~b} / \mathrm{v}(\mathrm{P}<0,05)$. Tidak ada perbedaan nyata dalam kandungan karbohidrat terlarut total jus buah Pir Yali antar perlakuan.

Korelasi antara konsentrasi asam sitrat dengan kandungan karbohidrat terlarut total jus buah Pir Yali ditunjukkan pada Gambar 3. 


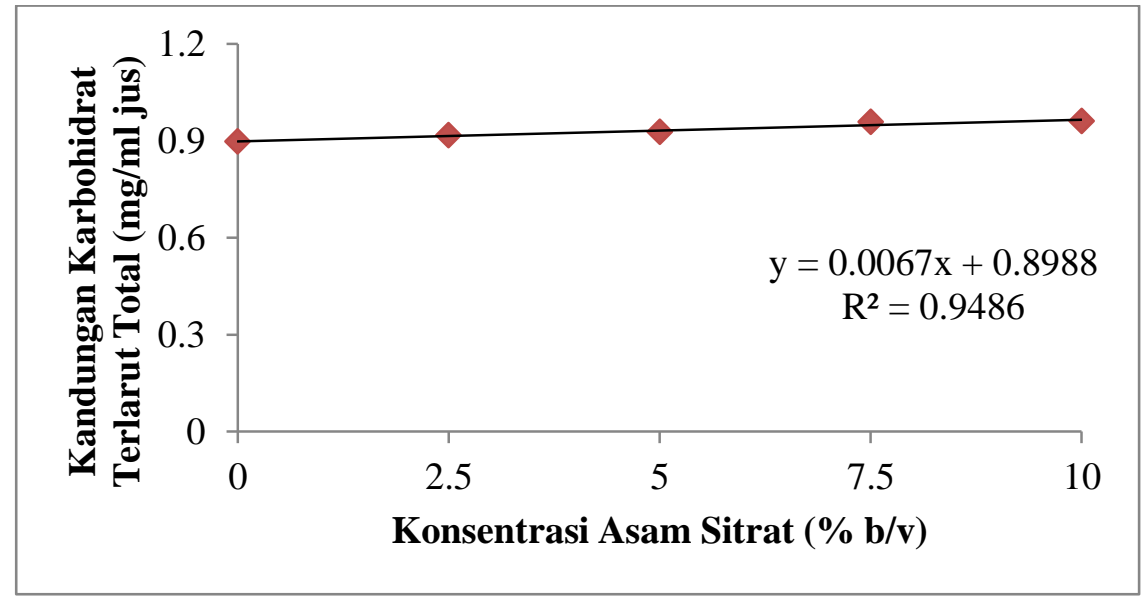

Gambar 3. Kurva regresi antara konsentrasi asam sitrat dengan kandungan karbohidrat terlarut total jus buah Pir Yali.

Analisis regresi menunjukkan bahwa konsentrasi asam sitrat berkorelasi linear positif dengan kandungan karbohidrat terlarut total jus buah Pir Yali dengan koefisien determinasi adalah 0,948 dan koefisien korelasi adalah 0,974 yang menunjukkan hubungan yang kuat antara konsentrasi asam sitrat dengan kandungan karbohidrat terlarut total jus buah Pir Yali.

Aktivitas Enzim Dehidrogenase. Aktivitas enzim dehidrogenase didalam jus buah Pir Yali setelah dipanaskan pada suhu $60^{\circ} \mathrm{C}$ dan ditambahkan asam sitrat dengan lama diinkubasi 72 jam dapat dilihat pada Gambar 4.

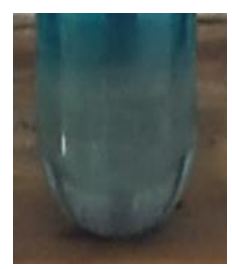

$0 \% \mathrm{~b} / \mathrm{v}$

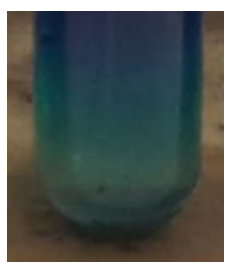

$2,5 \% \mathrm{~b} / \mathrm{v}$

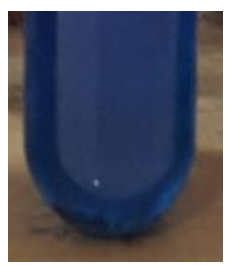

$5 \% \mathrm{~b} / \mathrm{v}$

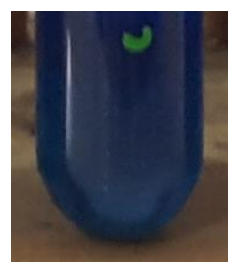

$7,5 \% \mathrm{~b} / \mathrm{v}$

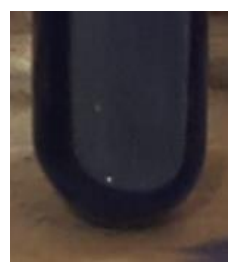

$10 \% \mathrm{~b} / \mathrm{v}$

Gambar 4. Aktivitas enzim dehidrogenase jus buah Pir Yali

Berdasarkan dari hasil pengamatan terlihat bahwa warna methylene blue kontrol lebih terang dari warna warna methylene blue perlakuan. Hal tersebut menunjukkan penurunan aktivitas enzim dehidrogenase terjadi sejalan dengan peningkatan konsentrasi asam sitrat. Hal tersebut diduga terjadi karena elektron yang dilepaskan oleh jus buah pir kontrol lebih banyak daripada elektron yang dilepaskan oleh jus buah pir perlakuan. Enzim dehidrogenase merupakan enzim yang terlibat dalam siklus Krebs, oleh karena itu siklus Krebs mengalami penurunan pada jus buah pir perlakuan karena enzim tidak dapat bekerja dalam kondisi asam (Manopoulou and Theodros Varzakas, 2011).

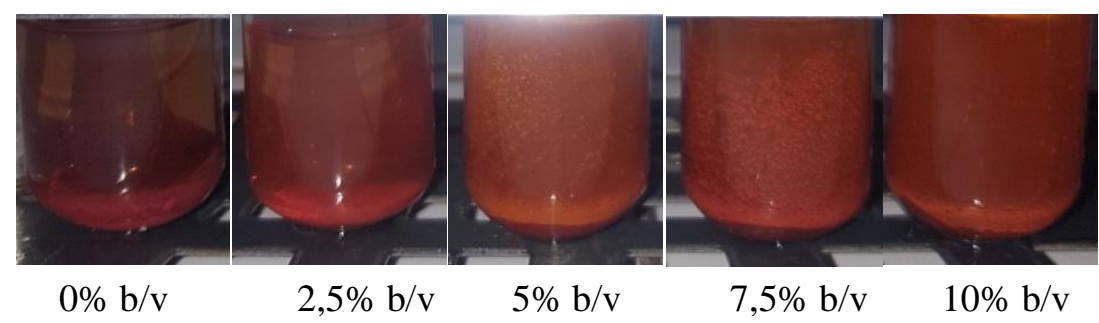

Gambar 5. Level gula pereduksi jus buah Pir Yali 
Level Gula Pereduksi. Level gula pereduksi didalam jus buah Pir Yali setelah dipanaskan pada suhu $60^{\circ} \mathrm{C}$ dan ditambahkan asam sitrat dengan lama diinkubasi 72 jam dapat dilihat pada Gambar 5. Hasil penelitian ini menunjukkan bahwa level gula pereduksi mengalami peningkatan sejalan dengan peningkatan konsentrasi asam sitrat. Hal ini diduga karena tidak terjadi reaksi Maillard dalam perlakuan sehingga gula pereduksi tidak berikatan dengan gugus amino dalam reaksi Maillard (Whistler and Daniel, 1985).

\section{KESIMPULAN DAN SARAN}

Asam sitrat pada konsentrasi 7,5\% b/v bersifat inhibitor proses non-enzimatik browning dan aktivitas enzim dehidrogenase, namun stimulator kandungan karbohidrat terlarut total dan level gula pereduksi.Saran diberikan atas dasar hasil penelitian untuk menutupi kekurangan penelitian apabila dilanjutkan. Tidak memuat saran-saran diluar untuk penelitian lanjut. Sehingga perlu dilakukan penelitian lanjutan untuk mengukur aktivitas enzim dehidrogenase dan gula pereduksi secara kuantitatif.

\section{DAFTAR PUSTAKA}

Arsa, Made, 2016. Proses Pencoklatan (Browning Process) Pada Bahan Pangan. Jurnal Kimia Udayana. Denpasar.

Azis, R. 2016. Pencoklatan pada Buah Pear. Teknologi Hasil Pertanian Poligon. Gorontalo.

Buckle, K.A. 1987. Ilmu Pangan. Universitas Indonesia Press. Jakarta.

Blackwell, Wiley, 2012. Food Biochemistry and Food Processing. 2nd(ed). New York. Amer. Soc. Horts. Sct. $120(5): 835-838$.

De Man, J.M. 1997. Kimia Makan. Institut Pertanian Bogor. Bogor

Eriksson, C. 1981. Maillard Reaction in Food: Chemical, Physiological and Technological Aspects. Pergamon Press. Oxford.

Eskin, N.A.M., H.M. Henderson, and R.J. Townsend. 1971. Biochemistry of Foods. Academic Press, New York, San Francisco. London.

Iyengar,R.J.A. and Evily.1992. Anti Browning Agent : Alternatives to the use of sulfite in foods ;Trends in food Technology. Elsevier trends Journal. 3: 60-63

Jeong, H.L., Jin, W. J., Kwang, D.M., and Kee, J.P. 2008. Effect of anti-Browning Agents on Polyphenolozidase Activity and Total Phenolics as Related to Browning of Fresh-Cutfuji' Apple. ASEAN Food Journal. 15(1): 79-87.

Manolopoulou, E., and Theodoros Varzakas. 2011. Effect of Storage Conditions on the Sensory Quality, Colour and Texture of Fresh-Cut Minimally Processed Cabbage with the Addition of Ascorbic Acid, Citric Acid and Calcium.

Padmadisastra Y, Sidik, Ajizah S. 2003. Formulasi sediaan cair gel Lidah Buaya (Aloe vera Linn.) sebagai minuman kesehatan. Fakultas Farmasi. Universitas Padjadjaran. Bandung.

Pradhana, Adhitya Yudha dan Karouw, Steivie. 2016. Pencegahan Pencoklatan dan Kekerutan pada Permukaan Sabut Kelapa Muda dengan Antioksidan. Balai Penelitian Tanaman Palma. Manado.

Rahmawati F. 2008. Pengaruh vitamin C terhadap aktivitas polifenol oksidase buah Apel merah (Pyrus malus ) secara in vitro. Skripsi Universitas Muhammadiyah Surakarta. Surakarta. 
Wijaya, Belina Arum. 2008. Perbandingan Efek Antibakteri dari Jus Pir (Pyrus bretschneideri) Terhadap Streptococcus mutans pada Waktu Kontak dan Konsentrasi yang Berbeda. Fakultas Kedokteran Undip. Semarang.

Witham H.F., D.F. Blaydes and R.M.Delvin. 1986. Exercieses in Plant Physiology. Second Edition. Prindle, Weber and Schmudt Publisher, Boston.

Wulandari, Catur. 2016. Pengaruh Asam Sitrat Terhadap Indeks Browning, Kandungan Karbohidrat Terlarut Total, dan Aktivitas Enzim Dehidrogenase pada Buah Pir Yali (Pyrus bretschneideri Rehd.). Universitas Lampung. Lampung.

Whistler R., Daniel JR. 1985. Carbohydrate. Di dalam: Fennema OR (eds). Food Chemistry. New York. Marcel Dekker. Inc.

Zulfahnur, 2009. Mempelajari Pengaruh Reaksi Pencoklatan Enzimatis Pada Buah Dan Sayur. Institut Pertanian Bogor. Bogor. 